\title{
THE CHRISTIAN RESPONSE TO POVERTY: IMPLICATIONS FOR THE 21st CENTURY CHURCH
}

\author{
John SIRENGO1 \\ DOI: $10.35782 / J C P P .2021 .1 .04$
}

\begin{abstract}
The concept of poverty is multifaceted as regards to bumanity because of its description as being spiritual and material. From its antiquity, poverty has contributed to hunger and other related effects such as diseases which have fuelled the devastations of global community in matters of food production. This article focuses on the Christian response to poverty and its implications to the 21st century Church. It addresses the nature of poverty as absolute and relative. The causes based on the Church's historical proponents, theologians and biblical causes are bighlighted. In its implications, one should take a holistic approach towards human sustenance of good life. God is the source of this wealth and material possessions are good and valuable, that man should not pride with it in exclusion of God. In conclusion, transformation of the sinful bumanity is the beginning of the alleviation of both spiritual and material poverty. Stewardship and generosity are the gateway out of poverty.
\end{abstract}

Keywords: Christian response, poverty, implications, Church

\section{Introduction}

The idea of poverty is systematically associated to man. Poverty is as old as man himself; hence, the eradication of poverty is very multifaceted. Around the globe poverty is explicitly an obstacle to many achievements. For example extreme hunger may lead to dangerous diseases that may cause man to become un-functionable in matters of efficiency in production.

If Christians are to respond to the extreme perils of poverty, they may first positively interpret Jesus' assertion that "for you always have the poor with you" (Matthew 26:11 ESV). This statement is negative, but should follow Jesus' teachings on the poor and how he advocated for their welfare. Secondly, they should find out the causes and nature of

${ }^{1}$ Lecturer, Friends Theological College-Kaimosi, P.O. Box 9, Tiriki, 50309, Kenya. Website: http:/ / ftc.friendsunitedmeeting.org; E-mail: ftc@fum.org 
poverty in order to come out with comprehensive and lasting solutions. Since there are various understanding of the nature of poverty, then the perspectives may also vary in response.

The paper will also focus on the Church's historical proponents on how poverty was viewed and their response to it. A biblical perspective is the core for the findings about the issue of poverty as a peril to many communities. Theologians on the other hand will be essential in the understanding of how poverty should be addressed to reduce its courses to the populace. On the other hand the findings will be recollected for proper applications and making a strong and lasting solution.

\section{Definition of Key Terms}

i. Christian: According to Webster Dictionary, the term Christian is defined as "a person professing belief in Jesus as the Christ, or in the religion based on the teachings of Jesus" (Webster's New World Dictionary of the American Language, 1966: 259-260).

ii. Response: The word response in the Webster's Dictionary is defined "as something said or done in answer to the something else" (ibid: 1240).

iii. Poverty: The term poverty is defined as "the condition or quality of being poor or indigent" (ibid: 1144). It also adds that it is a "deficiency in necessary properties or desirable qualities, or in a specific quality" (ibid).

iv. Church: The term Church is defined as "the ecclesiastical government of a particular religious group, or its power, as opposed to secular government" (ibid: 262).

\section{The Concept of Poverty}

The concept of poverty may vary from time to time and from one geographical area to the other. Poverty is complex to define and it also poses a challenge in the measurement of its status. Both the Old and the New Testaments have different etymological understanding of the term poverty. On the same note, the secular perspective also varies as per jurisdiction of its effectiveness. In this case, poverty can be understood as either absolute or relative:

a. Absolute Poverty: The word absolute may be understood as something being independent of its own, without any comparisons. However, Kunhiyop (2008) defines the word 'absolute' as "the inability to afford a minimum standard of living".

b. Relative Poverty is the relationship between the poor as compared to others in a given community in matters of resources and income. Peter Town Ford in Kunhiyop's book African Christian Ethics defines 'relative poverty' as "the absence of inadequacy of those diets, amenities, living standards, services and activities which are common customaries in society" (Kunhiyop, 2008). 
52 The Christian response to poverty: implications for the 21 st century church

\section{The Causes of Poverty}

The causes of poverty may vary from community to community. For example, the World Book Encyclopedia (1992: 728) mentions the first one as "the inability of certain people to get or hold steady, well-paying jobs. Many of these lack the education, skills, or talent needed for such jobs, other people are too old or sick to work". Many times people lack the ability to acquire good jobs. For example, education is the key to employment, skills are part of the training that can make one to be self-employed or be employed by other people or companies. On the same note, it is related to physical weakness in which Myers (2006: 67) observes that "the household members are weak. They lack strength because of poor health and inadequate nutrition. Many in the household are women, the very young, and the very old". It is also noted that "the economic forces and changes in labor requirements also causes poverty" (World Book Encyclopedia, 1992: 728). When the economy rises, the value of money goes down and this may cause the inflation to affect both workers and the common man. On the side of the workers, they may loose their jobs due to lack of enough money for their payments. While with the common man the prices may go up or the supply of goods may become scarcity as a result people misses to have adequate food.

On the one hand, technology is sufficient in making the work easier and faster in its accomplishment. But on the other hand, "advances in technology may cause unemployment and poverty among workers whose jobs are taken over by machines" (Myers, 2006: 67). For example, the use of combine harvesters in farms of wheat and maize in Kenya caused many people to loose their jobs. When factories close down many people becomes unemployed. As a result poverty dominates because there would be no enough money in circulation. For example, when the Pan Paper Factory in Western Kenya closed down, approximately 2000 people lost their jobs.

Social forces have been noted as a cause of poverty. For instance, "certain employers purposely try to avoid biring blacks and other members of minority groups" (World Book Encyclopedia, 1992: 728). It is a case also in the Kenyan system in certain counties where inflation in economy has caused unemployment to many people. When such situations take place, poverty dominates in many people's lives and thus hunger and other related effects like diseases spreads. Myers has observed that "the household lacks the ability and the knowledge to influence the life around it and the social systems in which it lives" (Myers, 2006: 67). If any government may take less control in social relationships the minority groups may remain poor for many years. The above causes of poverty were in line with the perspectives of World Encyclopedia's definition of poverty as "the lack of enough income and resources to live adequately by community standards" (World Book Encyclopedia, 1992: 727). Since these causes vary from place to place and from county to country, it is difficult to come up with the proper measuring standards of control. The world Book Encyclopedia has suggested three major measures for eliminating poverty, firstly, "measures to improve job opportunities, secondly, education programs, and thirdly, social welfare programs” (World Book Encyclopedia, 1992: 728). 


\section{Biblical Causes of Poverty}

The major biblical causes of poverty are related to the rebellion of man against God. Sin becomes the cause of poverty among the first parents of humanity, Adam and Eve. From the consequences of the fall of man in the Garden of Eden, man therefore faces the challenge of survival and suffering. In Genesis 3:18-19, God pronounces a curse to the land and humanity as a whole, "it will produce thorns and thistles for you and you will eat the plants of the field. By the sweat of your brow you will eat your food until you return to the ground, since from it you were taken, for dust you are and to dust you will return" (Genesis 3:18-19. NIV). As a result of this, poverty is seen as spiritual and material. Man is alienated from God and begins a wondering life. This has affected the entire human race in the world. God in his mercy, provided for Adam and Eve laws to govern them. The book of Exodus 23:2, 6,7 NIV records:

When you give testimony in a lawsuit, do not prevent justice, by siding with the crowd (verse 6). Do not deny justice to your poor people in their lawsuits. When you give testimony in a lawsuit, do not pervert justice by siding with the crowd (verse 7). Have nothing to do with a false charge and do not put an innocent or honest person to death, for I will acquit the guilty.

As time went by, man could not withhold the laws and therefore corruption entered among the kings and other leaders. Poverty in this state affected man and therefore he continued to suffer without any remedy.

\section{a. Holy Poverty}

The Oxford Companion to Christian Thought describes Holy Poverty as that "which renounces material wealth, frees people to serve others and keeps them close to and reliant on God" (Hastings, 2000: 552). The Holy Poverty was more of serving God in the spiritual without having the material wealthy. So whosoever focuses on the material things fells into poverty. The disciples of Jesus Christ decided to leave everything and followed Jesus. The Bible records, "and when they had brought their boats to land, they left everything and followed him" (Luke 5:11 ESV). Jesus had encouraged his disciples to sell everything in acceptance of serving God without the involvement of the material things. In the gospel of Matthew 19:21, "if you would be perfect, go, sell what you possess and give to the poor, and you will have 'treasure in heaven; and come, follow me" (Matthew 19:21, ESV). It was a warning against acquiring of riches and the pursuit of wealthy without considering the poor.

This Holy Poverty was in the minds of the early church fathers that strongly rejected the practice of material wealth. Material wealth was a destructive towards knowing God the Maker and Provider of every human need. Cyprian of Cathege had to say that:

The property of the wealthy holds them in chains... which shackle their courage and choke their faith and bamper their judgment and throttle their souls. They think of themselves as owners, whereas it is they rather who are owned: enslaved as they are to their own property, they are not the masters of their money but its slaves (Kangas, 2012; retrieved online on 28th June 2020). 
54 The Christian response to poverty: implications for the 21 st century church

\section{b. Laziness/Lack of Intelligence}

Laziness and lack of intelligence were the causes of poverty in the Old and New Testament understanding. It is an idea that "the poor have only themselves to blame [...]" (Hastings, 2000: 552). Therefore, poverty comes as a result of God's punishment to those who lack the ability to think and find food. Job's poverty, as he lost everything, was termed by his friends as a punishment from God. It is written in Job 4:7-9, that "who that was innocent ever perished? Or where were the upright cut off?... By the breath of God they perish, and by the blast of his anger they are consumed" (Job 4:7-9, ESV). On the same note, Jesus, according to the gospel of Matthew 25:28, castigated those who did not put their initiatives in the use of talents to produce profit. Jesus said to one of them, "so take the talent from him and give it to him who has the ten talents" (Matthew 25:28, ESV).

The lack of intelligence is one of the causes of poverty. Myers (2006: 84), asserts that "poverty is caused in part by lack of knowledge and technical information". The mental aspect of man is important in the fact that he/or she should be knowledgeable on matters of spiritual and physical wealth. Those who involve themselves in drugs and alcohol may increase the inability of the mind and the spirit to think and act as God made it. The Bible is also clear as it mentions in the book of Hosea 4:6 (ESV) that "my people are destroyed for lack of knowledge". Knowledge as a process could cause some people to acquire it adequately and understand quickly while others would be slower. Therefore, Clement of Rome (1st Century) understood it as the strong taking the initiative towards the weak:

Let the strong take care of the weak; let the weak respect the strong. Let the rich man minister to the poor man; let the poor man give thanks to God that he gave him one through whom his need might be satisfied (Kangas, 2012; retrieved online on 28th June 2020).

\section{c. Injustice}

Injustice done by the rich to the poor is against God's laws. God instructed Prophet Amos to proclaim the prophetic message to the corrupt and unjust Kings and Judges who exploited the poor by not giving them their rights of pay after working for them. In Amos 4:1 ESV: "who oppress the poor, who crush the needy". Injustice done by the rich on the poor is one of the causes of poverty among the community. This implies the imbalance of life in economic and social life to the people. It may also mean exploitation of the poor by the power of wealth to manipulate the poor to worship the rich in honouring them as their providers. God in his words of Proverbs 14:31 ESV proclaimed to the community that "whoever oppresses a poor man insults his maker, but he who is generous to the needy honors him". Generosity is the key to fulfilling the command of God towards the rich and the poor. It is warning towards the rich to disburse and share their wealth to the needy by fulfilling the law of God. Failure to do, Irenaeus commended that:

Instead of the tithes which the law commanded, the Lord said to divide everything we have with the poor. And be said to love not only our neighbors but also our enemies, and to be givers and sharers not only with the good but also to be liberal givers toward those who take away our possessions (Kangas, 2012; retrieved online on 28th June 2020). 


\section{The Practical Response to Poverty}

Practically, the existence of poverty has its meaning in a broad spectrum of understanding. The church has been given the spiritual and material responsibilities to liberate the deprivation of the human condition of spiritual and physical poverty. For this case, the following are the practical approaches towards the eradication of spiritual and material poverty:

\section{a. Be Salt and Light of the World}

The use of salt and light is metaphorically described by Jesus Christ in the gospel of Matthew 5:13-14 ESV, that "you are the salt of the earth; you are the light of the world". This meant that Christians should preserve the truth and teach the world the knowledge of how humanity should come out of the sin that has entangled it into both spiritual and material poverty. The late Tokunboh Adeyemo (2006: 14) asserts in "Is Africa Cursed?" that "as salt is used to arrest the process of decay and add taste to the insipid, and as light dispels darkness and reveals the hidden things, so also are Christians expected to be in society". If Christians should accept Christ's call as salt and light of the world, all humanity would be freed from poverty. In the words of Kunhiyop (2008: 154), "if the church in Africa were to covenant before God and before each other to be uncompromisingly honest, to defend the poor, and to do all it can within its power to better their lives, it would indeed be a source of good news to the poor".

\section{b. Practicing the Golden Rule}

The practice of the Golden Rule is to those who understand the law of God loving of the neighbor and instilling peace to each other. Tokunboh (2006: 114) commented that "the Golden Rule implies patriotism, or love, for your nation". Love as an attribute of God should be practical within the rich and the poor as a fulfillment of God's law of the neighbor. This is the commitment of Christians to non-Christians to put into practice a brotherly love, by sharing and supporting the poor in their state of want.

\section{c. Positive Attitude towards Work}

The term 'work' appears in the Bible in the second chapter of Genesis (2:2 ESV) when God finished his creation ("By the seventh day God had finished the work he had been doing; so on the seventh day he rested from all his work"). This is the finishing purpose, as we work; we are finishing what God has already accomplished. The Bible indicates a positive focus towards work. Genesis 1 and 2 describe the type of work God demands from man. Shaw (2014: 61) asks “why do people work??", explaining that, "one of the primary longings of emerging adults is for great work. They may insist that they work simply to make money, but in their hearts they want work that satisfies their soul and makes the world a better place". The Protestant view of work has helped us understand work as being holistic in nature. In this sense, a holistic type of work has been introduced to satisfy the rational, the spiritual and the physical parts of man. 
56 The Christian response to poverty: implications for the 21 st century church

Those who practice this holistic understanding of work often fulfill God's mission. Tokunboh (2006: 117) asserts that "the Bible is serious about the importance of work". The church has to make serious practicum on what apostle Paul admonished in Thessalonians 3:10-11 ESV: "if anyone is not willing to work, let him not eat; for we hear that some among you walk in idleness, not busy at work, but busybodies". Here, work becomes a necessity towards accomplishing God's desires and for man to acquire food.

\section{d. Raising Godly Families}

Raising Christian families is a model of God's mission in this world beginning from Adam and Eve. The family unit has been affected from both spiritual and material decadence. Tokunboh (2006: 118) denotes that "such foreign perversions as homosexual and lesbian relationships are contributing to moral decadence and collapse of family units in our societies". The household has the responsibility of preserving God's creation by working together in unity (father, mother and children) as a replicated model of God the Father, God the Son and God the Holy Spirit working in Trinity. By behaving in this way, no poverty should exist within the family.

The Bible affirms family unit in training: "train up a child in the way he should go; even when he is old he will not depart from it" (Proverbs 22:6 ESV). A godly family that follows what is expected of them lives a well balanced life. It is what Tokunboh (2006: 119) calls " $a$ regular consistent family altar backed by a live of prayer, of holiness, of charity and of hard work is an investment that guarantees impressive dividends".

\section{e. Presenting the Whole Gospel}

Presenting the whole Gospel means that the spiritual, physical and mental needs of man have to be acquired. This is a holistic approach towards the eradication of poverty. Kunhiyop (2008: 158) says that "we are not only to people and to convert them, but are also to teach them how to live in a way that pleases God".

\section{Application}

It is important for Christians to defend the view that both material and spiritual wealth can coexist with godliness. Blomberg and Carson (1999) have illustrated five points in support of both material and spiritual possessions as in line with God's work. The first one is that, "material possessions are a good gift from God meant for his people to enjoy" (Blomberg, Carson, 1999: 243). It is evident that when God created the heavens and earth he eventually said that it is good. Nothing is wrong with material possessions. The second point mentioned is that "material possessions are simultaneously one of the primary means of turning buman hearts away from God" (ibid: 244). Beginning from Adam and Eve had coveted against the forbidden and attractive fruit in the Garden of Eden. Hostility and exploitation of the poor begins with much desire for material possessions. The idea is explicitly addressed by the pastoral writer Timothy (I) 6:10 ESV, who says "for the love of money is a root of all kinds of evils". Once more Paul encouraged Timothy not to appoint 
any person who loved the money. In I Timothy 3:3 ESV, he says "not a lover of money" should be involved in leadership capacities.

The heart of generosity is important in the service of God. Giving of tithes was encouraged both in the Old and New Testaments, at least to support the poor, widows, orphans and other social categories exposed to the risk of poverty. Blomberg and Carson (1999: 245) claim that "one of the most frequent refrains of Torah, Psalms and Prophets is God's concern for the widow, fatherless, alien and poor". This calls for transformation and stewardship among the ministers of God in the achievements of God's concern for his people. This however contributes to the third point, "a necessary sign of a life in the process of being redeemed is that of transformation in the area of stewardship" (ibid: 244).

The fourth point towards the skewed process of defending poverty depends upon the area affected. Blomberg and Carson (1999: 245) argue that "there are certain extremes of wealth and poverty which are in and of themselves intolerable". People or a certain community may be rich or poor depending on the economic setup that might affect them. Therefore, this may call in any material support to enhance the wellbeing of the people.

No single church can prosper spiritually without the material support. In their fifth point, Blomberg and Carson (1999: 246) note that "the Bible's teaching about material possessions is inextricably intertwined with more spiritual matters". If the church works on the one part, then the other part will be left incomplete which may mean poverty is half way solved. Balancing the two is important as a good steward of God's property. The gospel can be well spread with good contributions of funds out of which church workers are to be paid, or costs of travel and other socio-economic needs covered. The office of evangelism cannot work well without having good offertory and tithes in the church. There is need to have godly people who may be contended with the little or much wealth.

\section{Conclusion}

It is fundamentally important to note that eradication of poverty begins with the transformation of the sinful humanity. When man is redeemed from the prison of sin then the socio-economic life of man becomes manageable under God's control. Stewardship takes lead in both material and spiritual possessions. The church should try to gain the material and spiritual possessions because they are good from the beginning of creation of man. In the third letter of John $2 \mathrm{ESV}$ it is stated that "beloved, I pray that all may go well with you and that you may be in good health, as it goes well with your soul". Generosity and compassionate heart is a means of poverty reduction in cases of either in surplus or little possessions. Supporting the needy is indispensable because of the intolerable circumstances.

Churches that believe in the holistic ministry should enlarge their work to become global. Blomberg and Carson (1999: 247) are clear as they mention that "if bolistic salvation represents the ultimate good God wants all to receive, then our charitable giving should be directed to individuals, churches or organizations that minister holistically, caring for people's bodies as well as their spiritual circumstances". It is a call to the church to have a holistic Christian 
58 The Christian response to poverty: implications for the 21 st century church

who can carry out the work of God in a faithful manner to achieve the spiritual and physical needs of man.

\section{Authorship}

This work is John Sirengo's own research and it has not been surpoted by any external person.

\section{Acknowledgements}

This study was not surpoted in any kind whatsoever.

\section{Funding}

The author received no financial support for the research, authorship, and publication of this article, apart from the redactional assistance of the Journal of Community Postive Practices (JCPP) for publication.

\section{Declaration of conflicting interests}

The author, by the name John Sirengo, declares no conflicting interests within this article.

\section{References}

Blomberg, C. L., \& Carson, D. A. (1999). Neither Poverty nor Riches. A Biblical Theology of Possessions. Illinois: InterVarsity Press.

Hastings, A., Mason, A., \& Pyper, H. (2000). The Oxford Companion to Christian Thought. Oxford/New York: Oxford University Press.

Kangas, B. (2012). Teachings of the Early Church Fathers on Poverty \& Wealth. The Orant, available online at URL: https://www.patheos.com/blogs/billykangas/2012/08/teachingsof-the-early-church-fathers-on-poverty-wealth.html

Kunhiyop, S. W. (2008). African Christian Ethics. Zondervan: WaordAlive Publishers.

Myers, B. L. (2006). Working with the poor. Principles and practices of Transformational Development. New York: Orbis Books.

Shaw, M. (2014). Work, Play, Love: A Visual Guide to Calling, Career and the mission of God. Downers Grove: InterVarsity Press.

Tokunboh, A. (2006). Is Africa Cursed? A vision for the Radical Transformation of an Ailing Continent. Nairobi: WordAlive Publishers Limited.

Webster's New World Dictionary of the American Language. College Edition, New York: The World Publishing Company, 1966.

World Book Encyclopedia. Vol. 15. Chicago: World Book, Inc, 1992. 